\title{
WINE TOURISM AND AN EXAMINATION ON WINE TOURISTS' PREFERENCES AT KULA DESTINATION
}

\author{
Gürkan Akdağ \\ Abdoulaye Garba Bako \\ Kamil Yağci
}

\begin{abstract}
This study aims to determine overall profile characteristics of wine tourists who are visiting Kula destination and reveal their points of views on wine tourism. Findings of the study indicate that wine tourists generally are well educated, have high income and belong to middle or higher age groups. Other findings reveal that wine tourists are willing to travel long distances in order to have a wine tourism experience and they have plenty of leisure time besides not having monetary issues. On the other hand wine tourists' interest in wines generally show a long term relationship and travels towards wine tourism are quite preferred touristic activities by wine tourists. Furthermore, wine tourists are found out have a sophisticated palate. Results of the study support previous studies of the national and international literature. Attitudes and profile characteristics of wine tourists who are visiting Kula destination show similar properties which are towards different wine destinations. Finally, it is found out those wine tourists who are visiting Kula have little knowledge on the destination prior to their travel and they were expecting inferior supply elements regarding wine tourism at Kula destination before their visit. However their perceptions towards Kula changed in a positive manner after their experience.

Key words: Wine tourism, wine tourists, Vineyards, Kula destination
\end{abstract}

\section{INTRODUCTION}

Tourism is an indispensable element for today's globalized economies. Specifically mass tourism is an essential contributor in terms of economic and social impacts. However the destruction seen in destinations caused by mass tourism in years led to a quest for alternative and sustainable tourism types. Among the touristic activities of individuals in search for medical or cultural events, wine tourism has become a more preferred activity with each passing year. Wine tourism, in general, is touristic activities that has a main motivation of individuals to experience wines and travel. In the past, travels with a main motivation of wine were relatively low however nowadays, a rise in interest in wines and travel, increased leisure times, increased incomes and vineyards becoming more popular led to people travel more aware of the destination they travel to (Yüncü, 2010:30). This study aims to examine the concept of wine tourism as well as to determine overall profile characteristics of wine tourists who are visiting Kula destination and reveal their points of views on wine tourism.

WINE TOURISM AND WINE TOURISTS

\footnotetext{
${ }^{1}$ Assistant Professor, Mersin University, Tourism Faculty, Mersin, Turkey. e-mail: gurkanakdag@mersin.edu.tr
} 
Wine tourism may be described as a tourism activity emerging from travels of individuals or groups to vineyards, wineries and wine festivals, destinations with wine themes in order to develop their interest in wines (Illhan, 2009:258). Wine tourism is an approach that excels in the context of alternative tourism and special interest tourism all over the world today. Rise in income levels of individuals and parallel to that their tastes allows wine tourism to develop throughout the world. Napa Valley which is located in California, United States has become one of the most visited places, thanks to its wines.

The only reason for this high demand for Napa Valley which houses more than 200 vineyards, is wine and supportive touristic products presented with wine. Toscana region in Italy, Chile, South Africa and Australia are among the major destinations for wine tourism (Orcan, 2008:24). In Turkey, cities like Bozcaada, Cappadocia, Elazı and Diyarbakır have great potential in terms of wine tourism destinations. Wine tourists who are the fundamental element of wine tourism are individuals who are well educated, have high disposable incomes, seeking different levels of service, recreation and leisure and travel to destinations which present wine as the primary attraction (Y1ld1z, 2009:82). From a different perspective wine tourists may be described as individuals who are motivated mainly to experience wines and travel in order to reach this goal and attend to different wine activities in the places they travel to. It is quite difficult to propose a single description on who the wine tourists are and their characteristics. It is possible to say that with regard to the related literature classification of wine tourists is mostly based on socio-economical and demographical features. However there are other psychological factors that may be used in describing who the wine tourist is. Factors like: individuals' motivations in participating wine tourism, life styles, overall interests, income levels and personality traits may be used to better understand the wine tourists' overall profiles (Galloway et al., 2008; Gronau and Kaufmann, 2009). However, it is also possible to say that individuals who have similar demographical characteristics may present very different wine tourism behaviors because of their different lifestyles (Bruwer, 2002).

Different studies trying to extract overall profiles of wine tourists have already been conducted by Mitchell, Hall and McIntosh (2000), Charters and Ali-Knight (2002), Hall and Mitchell (2008) in different periods however the most recent and agreed discrimination has been made by Pratt, (2014) which categorizes wine tourists into four segments; wine lovers, individuals with interest in wine, wine enthusiasts and individuals indifferent to wine.

\section{WINERIES AND WINE TOURISM REGIONS}

While wine tourists are the primary elements for wine tourists, wineries as well as wine regions are supportive elements. Wineries are important businesses that may create a primary travel motivation for wine tourists. Sales from cellars show both the reality of winery life and reflect an original feature. 
The location of wineries are important because they let visitors feel and connect to the place, to observe and examine the production places and process of wine. A well and neatly designed vineyard pushes the visitors towards buying local souvenirs, view wines from other regions of the world and taste different kinds of wine before buying them (Sharples, 2000: 30; Sezer,2006:35).

Wine was born around approximately BC 4000 in the Central Anatolia-GeorgiaArmenia triangle then spread to whole Mediterranean basin followed by Europe, reached its peak in France and then spread to the whole world. The world's most prestigious drinks today is produced in North and South America outside of Europe, in Australia, in Africa and Asia and is getting richer with each passing year (Sezer, 2006:55). In particular, countries like Australia and New Zealand are making progress every year, increasing their vineyards and wine production.

\section{SCIENTIFIC STUDIES PERFORMED IN DIFFERENT REGIONS ON WINE TOURISM}

High demand towards wine tourism resulted in an emergence of studies in related literature. When bound by geographical characteristics related studies may be seen in, Australia (Macionis, 1997; Dowling \& Carlsen, 1999), Canada (Hackett, 1998; Telfer, 2001; Williams and Kelly, 2001), Chili (Sharples, 2002), France (Thevenin, 1996; Frochot, 2000) Hungary (Szivas, 1999), Italy (Pavan, 1994) New Zealand (Beverland, 1998; Johnson, 1998; Mitchell and Hall, 2003), Spain (Gilbert, 1992), South African Republic (Preston-Whyte, 2000; Bruwer, 2003), United States (Peters, 1997; Skinner, 2000), Great Britain (Howley\& van Westering, 2000), Romania (Adrian, 2014), Greece (Alebaki and Iakovidou,2011) and in Turkey (Sezer, 2006; Y1ldız,2009; Yüncü,2010; Akdağ and Yağc1,2015).

\section{METHODOLOGY}

This study is based on a qualitative research methodology which accepts wine tourism as an alternative type of tourism and examines wine tourists on a destination basis.

The main purpose of qualitative studies is to present in depth descriptions to readers and to understand and interpret the ideas of the main actors of the study. (Yildirim ve Şimşek, 2013). Interview techique was used as the data gathering tool for this study which was designed as a qualitative research.

Interview technique was applied to wine tourists through semi-structured interview form. The reason for chosing the aforementioned approach is to let individuals to contribute with their own ideas other than the questions that were asked to them. 


\section{Study Population and Sample}

Study population consisted of wine tourists in Turkey. Difficulties in reaching the whole population in terms of both time and money resulted in choosing sampling method. With this in mind, only wine tourists who have visited Kula and consumed wine, encountered a wine tourism experience and would be able to convey their ideas were included in the sample. The sample consisted of 47 wine tourists who have met this criteria.

\section{Data Gathering Tool and Analysis Method}

In order to collect healthy data for a qualitative study, interview technique which would provide best results was chosen. The interview form which contained five open ended, semi structured questions was derived from studies of Charters and Ali-Knight (2002), Carmichael (2005), Getz and Brown (2006), Dawson et al.., (2011), Prat (2011), Pratt (2014), Guzman et al. (2014), Akdağ (2015). Table 1 contains the questions prepared for participants.

Table:1. Key Questions of the semi-structured interview

1.Can you describe your interest in Wine world. How long have you been interested in wines and winery?

2. In what category could you describe yourself as a wine tourist?

3.Has wine tourism been a primary motivation for your travels in recent years?

4. Has wine tourism been a secondary motivation for your travels in recent years?

5.What was the effect of your visit to Kula vineyards on your hedonistic emotions?

Data for the study was gathered between September $1^{\text {st }} 2014$ and September $1^{\text {st }} 2015$ through face to face interviews with wine tourists after their touristic experiences. The participants were asked key questions regarding their overall familiarity to wine world (Q1), their opinions on to what type of tourist category they belong to (Q2), motivational role of wine in touristic travels (Q3 and Q4) and finally the effects of their visit to Kula destination on their hedonistic emotions (Q5).

\section{FINDINGS AND EVALUATION}

\section{Findings on the Demographic Characteristics of Participants}

Frequency analysis of demographical characteristics of local tourists including their gender, age, marital status and education are described in this section and results are presented in Table 2 . 
Table:2. Demographical Characteristics of Individuals Who Took Part in the Study

\begin{tabular}{|c|c|c|c|}
\hline Variable & No(N) & Variable & No (N) \\
\hline Gender $(\mathbf{n = 4 7 )}$ & & Residency $(\mathbf{n = 4 7 )}$ & 11 \\
\hline Women & 21 & İstanbul & 21 \\
\hline Men & 26 & İzmir & 8 \\
\hline Age Group(n=47) & & Manisa & 5 \\
\hline 29 and below & 5 & Ankara & 2 \\
\hline Between 30-39 & 14 & Antalya & 0 \\
\hline Between 40-49 & 19 & Monthly Income(n=47) & 2 \\
\hline 50 and above & 9 & 2.000 TL and below & 8 \\
\hline Marital Status (n=47) & & $2001-4001$ TL & 37 \\
\hline Married & 38 & $4001-6000 T L$ & 11 \\
\hline Single & 9 & 6001 and above & 6 \\
\hline Education(n=47) & & Occupation $(\mathbf{n}=\mathbf{4 7})$ & 2 \\
\hline Elementary & 4 & Self Employed & 8 \\
\hline High School & 8 & Government Official & 20 \\
\hline College & 20 & Retired & \\
\hline Master & 11 & Manager & \\
\hline PhD & 4 & Business Owner & \\
\hline
\end{tabular}

Analysis of the gender characteristics of wine tourists participating in the study indicates a balanced distribution. While 21 of the participant wine tourists are women the remaining 26 were men. The majority of wine tourists who have visited Kula are married. The educational levels of wine tourists which in turn contribute to their intellectual levels are college or above. In terms of residency, Izmir, because of its proximity to Kula destination has been the major source of wine tourists. An analysis of monthly income levels of participants revealed that their average income levels are greater than of Turkey average. Finally in terms of profession it can be seen that the majority of the participants are business owners.

\section{Wine tourists' level of interest towards the wine world}

In order to identify the relationship of wine tourists that visit Kula destination with wine and their level of interest towards wine tourism, the following questions were asked primarily: What is your level of interest towards wine tourism? For how many years you are interested in wine? Once the answers given to these questions were analyzed it was found out that wine tourists are generally interested in wine for long years and that they follow wine world at an international scale. The detailed analysis of answers pointed out that the participant, coded KST19, and expressed his /her level of interest by stating the following words: "Wine has always been a passion for me since my childhood. Since we have our own vineyards and our amateur winery, I am in the wine 
world for almost 40 years." The participant, code KST40, summarized his interest towards the wine world by saying that, "I could learn the related features and basic concepts related to wine due to my wife's passion for wine after we got married. It is not possible for me to say that I was competent in this subject before, but for the last 12 years I am interested in the subject in depth." The wine tourist code KST24 suggested that he/she is new in the wine world but is closely interested in the subject, by stating the following words: "I have been following the wine world for the last 3 years. After I got retired I had the chance to spare time for myself and my hobbies and during this period, wine activities have substantially attracted my attention." KST28 explained his/her personal development on subjects of wine by saying that "I am interested in the subject for many years profoundly. My recommendation is a bedside book called Wine Grapes. It is a fundamental work that taught me the wine world and supplied me with information on wine." KST7 stated his/her interest on the subject and the economic dimensions of this interest by telling that, "My interest in the wine world goes back too far in the past and I guess it will continue for the rest of my life time. Regarding wine, I shop frequently and collect aged wine as investment." While KST35 combined his/her occupation with his presence in the wine world by saying the following words, "I am a food engineer, that's why on one side wine had been my focus of interest and on the other side my research area, therefore in the last 5 years I am present in the wine world," KST1 coded wine tourist summarized his/her specialty by saying "I have a goof command of the subject up to the point that I could write an article. I am in the wine world almost for 20 years and I consider myself as a mentor of this subject."

\section{SELF-CLASSIFICATION OF INDIVIDUALS ACCORDING TO THE WINE TOURISTS CATEGORY}

The second question prepared for the wine tourists visiting Kula is related to the wine tourist profiles defined in the literature. In this scope, primarily the classification on wine tourists is verbally explained to the wine tourists, then they were asked to state to which type of wine tourists they felt closer; thus, they were asked, within which category of wine tourists do you define yourself with? Once the answers given to this question are investigated, it was possible to observe that wine tourists predominantly are knowledgeable about wine, fond of wine and in profile consists of individuals who are interested in wine. Wine tourist, KST22, while defining himself/herself as keen on wine, explained his/her profile as "I am in the learning process when wine is considered and I participate in such activities as long as I find the time." Wine tourist, KST47, defined himself/herself as the casual wine tourist saying that "My friends asked me to join them while coming to these vineyards, my main purpose is to have a nice day. I am a wine tourist, but my priority is not wine." KST14 said "Wine is not a special interest or hobby for me, it is a life style. Thus, I am a wine lover." While wine tourist KST30 stated "I usually participate in the wine tourism activities with my friends. We have an elementary group which likes to be interested in wine and we come 
together frequently to experience wine," KST29 mentioned his/her interest on wine with the words, "I am knowledgeable on all phases on the production and consumption of wine and visiting wine cellars becomes a huge pleasure for me." Wine tourist, KST8, summarized his/her sensitivity on wine by saying, "Wine is such a meaningful drink all by itself, yet when there is the harmony between food and wine it creates an artistic effect." KST43 emphasized his/her attention in the phases of wine buying with these words: "It really gives me a great pleasure to taste and buy wine from the wineries at the destinations I visit. Because buying wine from the spots where production takes place removes my concerns about the originality of the wine." While KST16 stated, "I try to join trainings related to wine frequently. Because wine gains meaning as you learn," KST11 defined his/her personal profile by saying, "I am experienced on wine. Previously, I have visited both domestic and international wineries. Therefore, I am an individual who is highly invested in wine." As KST45 summarizes his curiosity on wine by saying, "I like to follow publications on wine and I want to improve myself as much as I find the chance," KST4 defined himself/herself as a wine enthusiast within the wine tourist profile by stating, "I am not fully built up in the subject of wine, yet my friend circle are really experts and I join to the activities with them, as I find the opportunity." KST9 claimed that he is beyond the profiles with the words, "I travelled to Napa Valley in the United States, and even to Chinati in Italy. I have an intense belonging to wine further than any categories." While KST 44 said, "I am a second level ranking, interested in wine tourist, because I want to improve myself on wine and I frequently make trips due to this reason," and finally wine tourist, coded KST46, summarized his/her profile definition as "I am a wine instructor. Wine is both my occupation and my hobby. Therefore, I can define myself as a wine lover."

\section{Wine as a primary motivation factor for travel}

The third fundamental question of the study focuses on the place of wine based travel actions on the lives of individuals and wine tourism as a primary travel factor. In this regard, the third question of the study is asked in the following form: "Has wine tourism been considered as a first priority travel motivation in the recent years?" As the responses to this question are investigated; wine tourist KST46 said "I often make trips with the purpose of wine tasting, since I define myself as a wine tourist. Due to this purpose, I visited most wine regions of Turkey," and KST10 mentioned wine tourism activities he conducted consistently by saying, "Wine becomes a first priority travel motivation factor for me at least once a year." KST15 informed about his/her participation to the organizations that take place about wine tourism with the following words: "The wine community that I am a member of definitely presents participation to vine harvest activities. Thus, I definitely present participation to vine harvest festivals every year." KST20 summarized the intellectual background provided by the travels he made by saying, "Maybe not every year, but as my financial situation allows, I take travels to vineyards from time to time. Wine tourism activities are educative as much as 
they are relaxing." KST26 presented information about the travels he/she made despite the intensity of life situations by stating, "Although it is very hard for me to spare time for wine tourism activities, I can participate in them by choosing places that are close to Izmir." KST31 explained his/her passion on the subject by saying, "I have conducted several international trips, including France and Italy. Experiencing wine is totally worth these distances." KST33 mentioned their regular travels in scope of wine tourism with the words, "My partner and I always loved to pursue different routes. Therefore, a new wine destination each year becomes a new excitement for us." KST37 explained his/her approach by saying, "Wine constantly becomes a travel activity for me. For example, I am getting prepared for a wine travel that would be held in Rioja, Ribera del Duero and Rueda regions in Spain. Here (Kula) is quite beautiful yet it is a destination that viticulture is practiced in more of an amateur level. Yet in Europe, there are more professional tours." Finally, KST38 shared his/her level of sensitivity on wine by saying, "Wine is definitely my fritst priority motivation factor. I joined Italy tour last year and while planning my travel route, I designed it centering on Tuscany. What could it mean to visit Italy without visiting Tuscany?"

\section{Wine tourism as a secondary motivation factor for travel}

The fourth question of the study is asked with the purpose to reveal the effect of the individuals' wine passion on their travels. With respect to this purpose, the question was formulated as: "Has wine tourism been considered as a second priority travel motivation in the recent years?" According to the analysis of the responses to this question it was found out that even during the cultural or relaxing travels made by the individuals, the organizations related to wine are followed and wine related activities are participated as they could find the opportunity. In the responses given to the question, KST3 informed about the travel he/she made by saying, "I made a trip to the United States of America in the extent of a cultural tour five years ago. It was a pleasant experience for me and while I was going over the routes that were were going to follow, I found out that Food \& Wine Classics in Aspen activity would be held on the $28^{\text {th }}$ of that month in the city of Aspen. Hereby, I both had my vacation and found the opportunity to join to a valuable festival on wine and food." KST13 mentioned that he/she followed organizations related to wine during normal touristic activities by saying, "Every time I decide on a vacation destination I examine the potential wine activities or organization that could take place at the destination. Therefore, for me wine is an experience that could find a place for itself in each of my travels." KST18 gave a detailed answer to the question with the words, "I always seek different alternatives except the sea, sand, sun trio in my vacations, hence it is highly pleasant to taste wine in the regions I travel to. For instance, I was on Avsa Island this summer, so that I could find the chance to experience regional wines that I had no clue of on this occasion." KST17 stated that it could be combined with alternative touristic activities by saying, "One of my personal hobbies is hunting and I travel frequently on this 
occasion. During our hunting tour in the Eastern Europe, particularly in Bulgaria I tasted wines that are made of Chardonnay and Merlot grapes. Hence I could create an opportunity for myself through which I could experience both hunting and wine." While KST27 said, "I went to Florence with a small group of people to experience gastronomy and even gourmet, but even before the journey started I focused on selecting the wines that I could try next with the food, " KST32 defined his/her personal views and the possibilities at hand by saying, "I am still young and the budget I spare for wine is minimalistic in parallel to my age. Yet even in the travels I make as a backpacker, local food experience and local wines are of utmost importance to me." Finally, KST39 expressed the importance of viticulture, wine tourism and related activities on an individual level, with the words: "Wine sometimes becomes primary and sometimes the secondary travel factor for me. In addition, I definitely want to examine the local drinks, and if exists local wines, and want to visit the vineyards that the grapes for these wines are cultivated."

\section{Kula as a wine destination and the level of satisfaction of the visitors}

Fifth and the last question of the study is formulated to reveal the wine tourism experience that the wine tourists obtain and the contribution of visiting Kula destination on their hedonistic emotions. The final question was designed as, "What is the contribution of visiting Kula vineyards to your hedonistic emotions?" Once the responses to this question are scrutinized, wine tourist KST2 summarized his/her views on Kula and the travel with the words, "Kula is an obscure touristic destination, in this sense it is the exact place I am looking for. It was quite a calm and peaceful experience in personal scope. I was highly satisfied with the wine tourism activity I participated in Kula." KST5 expressed his/her happiness by saying, "The travel I made to the vineyards of Kula was one of the best things I did for myself for such a long time. Because on this occasion I tasted wines such as Cabernet Sauvignon, Nerello Cappucchio, Cabarnet Franc, those I wanted to taste but could not find the opportunity for such a long time." KST12 expressed a general satisfaction about the destination by stating, "Both the accommodation and the wines were wonderful in Kula, but the splendidness of the food increases the interest towards the wine. Especially, different wine tastings held with different food becomes memorable." KST21 exhibited a different viewpoint by saying, "I was not very much interested in the environment during my Kula trip. Strolling around the vineyards, winetasting in open air along with cheese plates were highly pleasurable activities. Especially the diligence and attention of the personnel even in removing the cork was the most meticulous behavior I have seen for such a long time." KST23 summarized personal view with these words: "I found the chance to find the wines from rare grapes, my personal favorites such as Nerello Mascalese, Petit, which are scarcely found or when found do not provide the desired maturity everywhere." KST25 declared that he/she left the destination with great satisfaction by saying, "I discovered a totally new activity in Kula. Indeed, I have 
not seen a place that compliments wine and food together for a long time. Next September, we are planning a stay-visit here with a larger, crowded group of people." KST34 gave explicit information of his/her experience by saying, "I only made an internet search before coming to here (Kula) and actually came with a very undecided mind. I had a low level of expectation and I was pessimistic. Yet, I had the chance to experience a lot of different alternatives in Kula, such as "entertainment", "relaxation", "spending the day outdoors" and "buying wine", those a wine tourist would seek." Wine tourist KST36 emphasized the diversity of wine in the region with the words, "I am actually a gourmet and I like to taste different wines along with the food. Sturdy wines with full tastes here gave me an excellent food experience, especially with the heavy red meat dishes, which I like very much. Being able to find kinds of wine that can be consumed with every food distinguishes this destination from its equivalents." While KST41 summarized his/her experience saying, "I visited Kula during the vine harvest festivals. I experienced a very rich and full vacation beyond my expectations. Both the visual qualities of the environment and the taste of the wine were memorable," KST42 summarized his/her wine experience with the following words: "The last time I was impressed this much was at the wine tasting I participated at River Rhone in France. It is both a hidden geography and a place of wine varieties that should surely be experienced by the wine lovers. Kula really became the only wine destination that could surprise me for such long years."

\section{RESULTS AND DISCUSSION}

Nowadays, in all the world, wine tourists participate both the domestic and the international tourism movements and the tourists that desire a wine related experience conduct different travels with respect to their economic power. Turkey is highly attractive for wine tourists due to its wine production, consumption and the historical features related to viticulture in providing alternative experience opportunities.

Today, in many different regions of Turkey, wine grapes are cultivated in the vineyards and investments towards wine tourism are implemented. Especially in the recent years, destinations such as Bozcaada, Gökçeada, Tekirdağ, Şarköy, Mürefte, Kırklareli, Edirne, Çanakkale (Trachea Vineyard Route), Cappadocia are known as the regions that are highly promising and that present development as wine regions. In this scope, Kula is one of the destinations that present a breakthrough in subject of wine and that the wine tourists focused their attention to.

This study was intended to investigate the general profile characteristics of the wine tourists and their attitude towards the wine tourism in Kula destination, which is visited by more people in the last years in terms of wine tourism and is located in the western Turkey. Determining the general profile characteristics of the wine tourists that visit Kula destination and identifying their motivation factors related to wine tourism are among the sub-objectives of this study. The results obtained in this study with qualitative research design indicates that wine tourists are generally middle age or 
higher, highly educated, and are individuals from high income group. The abovementioned findings are in a supportive nature to the findings of the previously conducted studies in literature by Prat, (2011), Pratt (2014), Dawson et. al, (2011), Guzman et. al (2014) and Akdağ (2015). Wine tourists exhibit profile characteristics as people who do not consider kilometers or materiality for having a wine experience, and as people with high pleasures.

As the level of wine world is investigated for wine tourists, it was found in the scope of this study that there is predominantly a rooted background and a supreme interest towards wine. According to the wine tourists participated in this study, wine tourism has a great influence on their choice of travel, both as a first priority and as a secondary motivation factor. Among the findings of the study, it was found that the wine tourism activities of the wine tourists, is not only a focus of travel at the local scale, but also international travels are commonly conducted.

As the classification of the wine tourists are made with respect to the wine tourist profile characteristics proposed by Pratt (2014), it is possible to observe that the individuals mainly define themselves as interested in wine or wine lovers. Very few of the individuals who define themselves as the wine tourists associate themselves as the "keen" or "uninterested" wine tourist profile.

The predominant approach indicates the presence of individual characteristics that afford to spend money on wine that is interested and intellectually equipped individuals in terms of wine subject. As the responses of the wine tourists on Kula destination and the hedonistic effects of the wine tourism experience are scrutinized, it is possible to observe that prior to the wine tourism experience, the wine tourists had low expectations on Kula and the destination seems to inhabit a perception that it would not be able to fulfil the expectations. Due to the behavior of the wine tourists after the experience, it is reached to the conclusion that there is a service and product quality that is above and beyond expectations, and that the individuals found the factors such as meat, cheese etc. as supportive products very satisfactory.

On the other hand, the presence of accommodation options that contribute to the experience of vineyards and wine tourism directly affects the satisfaction of the wine tourists.

As the presented findings are evaluated in general, the findings of this study are supportive in terms of the scientific studies that are conducted in international scale. Wine tourists who visit the Kula destination are individuals that are knowledgeable in wine, interested in wine, eager in spending money, have good financial situation, have a high level of education and are in the middle age or higher level group.

\section{REFERENCES}

1. Adrian, N. (2014). Potential of wine tourism in Romania, case study : Dealu Mare vineyard. Annals of the "Constantin Brancusi" University of Targu Jiu Economy Series, 50-55. 
2. Akdağ, G. (2015). Trakya bağ rotasını takip eden yerli turistlerin şarap turizmi deneyimleri, Journal of Tourism and Gastronomy Studies,3,4,3-11.

3. Akdağ, G., and Yağc1, K. (2015). Tourism, Environment and Sustainability (Ed. Prof. Dr. Cevdet AVCIKURT, Prof. Dr. Mihaela DINU, Prof. Dr. Necdet HACIOĞLU, Prof. Dr. Recep EFE, Prof. Dr. Abdullah SOYKAN) in "General Profiles and Reasons to Visit Wine Regions of Wine Tourists: A Comparison of Bozcaada, Elazığ and Cappadocia Regions" St. Kliment Ohridski University Press, Sofia, Bulgaria.

4. Alebaki, M, and Iakovidou, O. (2011). Market segmentation in wine tourism : A comparison of approaches, Tourismos: An International Multidisciplinary Journal of Tourism 6 (1), 123-140.

5. Beşer, G. (2014). Türkiye'de Butik Şarap Sektörünün Pazarlama Karması Acısından İncelenmesi, (Yayımlanmamış Yüksek Lisans Tezi) Namık Kemal Üniversitesi Fen Bilimleri Enstitüsü, Tekirdağ.

6. Beverland, M. (1998). Wine tourism in New Zealand-Maybe the industry has got it right, International Journal of Wine Marketing, 10 (2), 24-33.

7. Bruwer, J. (2002). Marketing wine to Generation X consumers through the cellar door. The Australian and New Zealand Grapegrower and Winemaker. Vol. 467, pp.67-70.

8. Bruwer, J. (2003). South African wine routes: Some perspectives on the wine Tourism industry's structural dimensions and wine tourism product, Tourism Management, 24 (4), 23-435.

9. Carmichael, B. A. (2005). Understanding the Wine Tourism Experience For Winery Visitors in the Niagara Region, Ontario, Canada, Tourism Geographies, 7 (2), 185-204.

10. Charters, S. and Ali-Knight (2002). Who is the wine tourist?, Tourism Management, 23 (3), 311-319.

11. Dawson, H., Homes, M., Jacob, H., and Wade, R.I. (2011). Wine Tourism: Winery Visitation in the Wine Appelations of Ontario, Journal of Vacation Marketing, 17 (3), 237-246.

12. Dowling, R., Carlsen, J. (Eds.), (1999). Wine tourism: perfect partners. Proceedings of the first Australian wine tourism conference. Canberra: Bureau of Tourism Research.

13. Ergüven, M. H. (2015), Gastronomy and Wine Tourism as a Variety of Special Interest Tourism: Thracian Vineyard. Turkish Studies.Volume 10/10, P. 449-464.

14. Frochot, I. (2000). Wine tourism in France: a paradox. In Hall, M., Sharples, L., Cambourne, B., \& Macionis, N. (Eds.), Wine tourism around the world (pp. 6780). Oxford: Butterworth-Heinemann

15. Galloway, G., Mitchell, R., Getz, D., Crouch G. \& Ong, B. (2008). Sensation seeking and the prediction of attitudes and behaviours of wine tourists. Tourism Management, Vol. 29, No.5, pp.950-966. 
16. Getz, D. and Brown, G. (2006). Critical success factors for wine tourism regions: A demand analysis, Tourism Management, 27, 1, 146-158.

17. Gilbert, D. (1992). Touristic development of a viticultural region of Spain, International Journal of Wine Marketing, 4 (2), 25-32.

18. Gronau, W. and Kaufmann, R. (2009). Tourism as a stimulus for sustainable development in rural areas: A Cypriot perspective. Tourismos, Vol. 4, No.1, pp. 8396.

19. Guzman, T.L., Rodriguez, A. V., ve Garcia, J. R. (2014). Profile and Motivations of European Tourists on the Sherry Wine Route of Spain, Tourism Management Perspectives, 11, 63-68.

20. Hall, C. M. \& Mitchell, R. 2008. Wine marketing a practical guide, Oxford, Elsevier Ltd.

21. Hackett, N. (1998). Vines, wines, and visitors: a case study of agricultural diversification into winery tourism. Unpublished thesis, Master of Natural Resource Management, Simon Fraser University.

22. Howley, M., and Van Westering, J. (2000). Wine tourism in the United Kingdom, In Hall, C. M., Sharples, L., Cambourne, B., \& Macionis, N. (Eds.), Wine tourism around the world (pp. 175-189). Oxford: Butterworth-Heinemann.

23. İlhan, İ. (2009). Şarap turizmi, Fermani Maviş Anı Kitabı, Anadolu Üniversitesi Yayınları, No:1885, Eskişehir.

24. Johnson, G. (1998). Wine tourism in New Zealand-A national survey of wineries. University of Otago, unpublished thesis, New Zelland.

25. Macionis, N. (1997). Wine tourism in Australia: emergence, development and critical issues. Universityof Canberra, unpublished Master thesis.

26. Mitchell, R. D. and Hall, C. M. (2003). Seasonality in New Zealand winery visitation: An issue of demand and supply, Journal of Travel and Tourism Marketing, 14 (3/4), 155-173.

27. Mitchell, R., Hall, C. M. and Mc Intosh, A. 2000. Wine tourism and consumer behaviour. In: HALL, C. M., SHARPLES, L., CAMBOURNE, B. \& MACIONIS, N. (eds.) Wine tourism around the world. Oxford: Butterworth Heinemann.

28. Orcan, S. (2008). Gastronomi ve turizm, Gastronomi Dergisi, 68, İstanbul.

29. Pavan, D. (1994). L'Enoturismo tra fantasia e metodo. Vignevini, 21 (1/2), 6-7.

30. Peters, G. (1997). American winescapes: the cultural landscapes of America's wine country, Boulder: Westview Press/Harpers Collins

31. Pratt, M. (2011). Profiling Wine Tourists, More Than Just Demographics, 6th AWBR International Conference, Bordeaux Management School, France.

32. Pratt, M. (2014). Four wine tourist profiles, Academy of Wine Business Research, $8^{\text {Th }}$ International Conference, Germany, 970-980

33. Preston-Whyte, R. (2000). Wine routes in South Africa. In Hall, M., Sharples, L., Cambourne, B., \& Macionis, N. (Eds.), wine tourism around the world (pp. 102114). Oxford: Butterworth-Heinemann. 
34. Sezer, B. (2006). Bir turizm ürünü olarak şarap kültürünün Bozcaada turizmine etkileri, (Unpublished Master Thesis) Çanakkale Onsekiz Mart University, Institute of Social Sciences, Çanakkale.

35. Sharples, L. (2000). Organic Wines The UK Market: A Shift from Niche Market to Mainstream Position?", International Journal of Wine Marketing, Vol 12, Issue 1, S. 30-42.

36. Sharples, L. (2002). Wine Tourism in Chile: a brave new step for a brave new world. International Journal of Wine Marketing, 14(2), 43-54.

37. Skinner, A. (2000). Napa Valley, California: A Model of wine region development. In Hall, M., Sharples, L., Cambourne, B., \& Macionis, N. (Eds.), wine tourism around the world (pp. 283-296). Oxford: Butterworth-Heinemann.

38. Szivas, E. (1999). The Development of Wine Tourism in Hungary, International Journal of Wine Marketing, 11(2), 7-18.

39. Telfer, D. (2001). From a wine tourism village to a regional wine route: an investigation of the competitive advantage of embedded clusters in Niagara, Canada. Tourism Recretion Research, 26(2), 23-33

40. Thevenin, C. (1996). Quands le vignerons font du tourisme. Espaces, 140, 43-48.

41. Williams, P., and Kelly, J. (2001). Cultural Wine Tourists: Product Development Considerations For British Columbia's Resident Wine Tourism Market, International Journal of Wine Marketing, 13(3), 59-77.

42. Yıldız, Ö. E. (2009). Türkiye'de şarap turizmi-Çeşme örneğinde ürün geliştirme modeli, (Unpublished Master Thesis) Dokuz Eylül University, Institute of Social Sciences, İzmir.

43. Yıldırım, A., and Şimşek, H. (2013). Sosyal Bilimlerde Nitel Araştırma Yöntemleri. Ankara: Seçkin Yayıncılık.

44. Yüncü, H. R. (2010). Şarap turizmi bölgelerinin rekabet edebilirliğine yönelik bir model önerisi: Kapadokya örneği, (Unpublished PhD Dissertation) Anadolu University, Institute of Social Sciences, Eskişehir. 